\title{
Patient stratification and genomics: flares, fizzlers and foxes
}

\author{
Kenneth GC Smith \\ From 7th European Workshop on Immune-Mediated Inflammatory Diseases \\ Noordwijk aan Zee, the Netherlands. 28-30 November 2012
}

Diseases have traditionally been defined predominantly by clinical criteria, sometimes with the assistance of "conventional" laboratory data. Recent advances in genomic technology have begun to find previously undiscovered sub-divisions within what were thought to be single diagnoses, sometimes with significant clinical implications. This talk will discuss the potential for such technologies to redefine the classification and treatment of autoimmune diseases, using two recent examples from Cambridge.

The first is the use of a Genome Wide Association Study to determine the genetic underpinning of ANCAassociated Vasculitis (AAV). This study has confirmed a genetic component to AAV pathogenesis, and demonstrated that the AAV clinical syndromes granulomatosis with polyangiitis (GPA: formerly Wegener's) and microscopic polyangiitis (MPA) are genetically distinct diseases better defined by ANCA specificity for proteinase-3 (PR3) or myeloperoxidase (MPO) rather than clinical syndrome. In addition the response against the autoantigen PR3 (encoded by PRTN3) was found to be a central etiological feature of PR3-ANCA associated vasculitis. Thus PR3and MPO-ANCA-associated vasculitis must be considered as distinct autoimmune syndromes [1].

The second example will describe the use of whole genome transcriptome analysis of purified CD8 T cells to define two sub-groups within patients with a number of inflammatory diseases (including SLE, AAV, Crohn's disease and ulcerative colitis). These otherwise "invisible" groups have markedly different long term outcomes [2,3]. This has implications for therapy, and has led to the development of a biomarker now entering clinical trials. Follow-up studies have led to the discovery of a new

Cambridge Institute for Medical Research and Dept. of Medicine, University of Cambridge School of Clinical Medicine, Addenbrooke's Hospital, Cambridge, UK inflammatory pathway controlling TNF $\alpha$ and IL-10 production that might drive this difference in outcome.

Published: 28 November 2012

\section{References}

1. Lyons PA, Rayner TF, Trivedi S, Holle JU, Watts RA, Jayne DRW, Baslund B, Brenchley P, Bruchfeld A, Chaudhry AN, Cohen Tervaert JW, Deloukas P, Feighery C, Gross WL, Guillevin L, Gunnarsson I, Harper L, Hrušková Z, Little MA, Martorana D, Neumann T, Ohlsson S, Padmanabhan S, Pusey CD, Salama AD, Sanders J-S F, Savage CO, Segelmark M, Stegeman CA, Tesař V, Vaglio A, Wieczorek S, Wilde B, Zwerina J, Rees AJ, Clayton DG, Smith KGC: Genetically distinct subsets within ANCA-associated vasculitis. N Engl J Med 2012, 367:214-223.

2. McKinney EF, Lyons PA, Carr EJ, Hollis JL, Jayne DRW, Willcocks LC, Koukoulaki M, Hatton A, MacAry PA, Brazma A, Chaudhry AN, Smith KGC: A CD8+ memory $T$ cell transcription signature predicts prognosis in autoimmune diseases. Nature Medicine 2010, 16:586-589.

3. Lee JC, Lyons PA, McKinney EF, Sowerby JM, Carr EJ, Bredin F, Rickman HM, Ratlamwala H, Hatton A, Rayner TF, Parkes M, Smith KGC: Gene expression profiling of CD8+ T cells predicts prognosis in patients with Crohn disease and ulcerative colitis. J Clin Invest 2011, 121:4170-4179.

doi:10.1186/1479-5876-10-S3-I5

Cite this article as: Smith: Patient stratification and genomics: flares, fizzlers and foxes. Journal of Translational Medicine 2012 10(Suppl 3):15.

Submit your next manuscript to BioMed Central and take full advantage of:

- Convenient online submission

- Thorough peer review

- No space constraints or color figure charges

- Immediate publication on acceptance

- Inclusion in PubMed, CAS, Scopus and Google Scholar

- Research which is freely available for redistribution
C Biomed Central

(c) 2012 Smith; licensee BioMed Central Ltd. This is an Open Access article distributed under the terms of the Creative Commons Attribution License (http://creativecommons.org/licenses/by/2.0), which permits unrestricted use, distribution, and reproduction in any medium, provided the original work is properly cited. 